\title{
The Tissue-Selective Estrogen Complex (TSEC): A Promising New Therapy for Menopausal Symptoms and Postmenopausal Osteoporosis
}

\author{
Sebastian Mirkin • James H. Pickar
}

Published online: 17 February 2012

(C) Springer Science+Business Media, LLC 2012

\begin{abstract}
The menopausal transition may be associated with bothersome symptoms and increased risk of osteoporosis that can decrease quality of life for women. The primary treatment option is hormone therapy, which has been associated with some safety and tolerability concerns. The tissue-selective estrogen complex (TSEC) is a novel therapy that pairs a selective estrogen receptor modulator with one or more estrogens. The first TSEC in clinical development partners bazedoxifene (BZA) with conjugated estrogens (CE) and has been evaluated in the phase 3 Selective estrogens, Menopause, And Response to Therapy (SMART) trials. BZA $20 \mathrm{mg} / \mathrm{CE} 0.45$ and $0.625 \mathrm{mg}$ have been shown to be effective in reducing the frequency and severity of hot flushes and improving measures of vulvar/ vaginal atrophy. These BZA/CE doses have also been shown to increase bone mineral density and reduce bone turnover without stimulating the endometrium and breast. $\mathrm{BZA} / \mathrm{CE}$ represents a promising new therapy for postmenopausal women.
\end{abstract}

Keywords Menopause · Osteoporosis · Estrogen · Selective estrogen receptor modulator · SERM - Bazedoxifene · BZA/ CE - Tissue-selective estrogen complex · TSEC - Safety · Efficacy · Hot flushes · Vasomotor symptoms · Vulvar/ vaginal atrophy $\cdot$ Bone mass $\cdot$ Clinical trials

\section{S. Mirkin $(\bowtie)$}

Pfizer Inc,

500 Arcola Rd, Room B-4250,

Collegeville, PA 19426, USA

e-mail: Sebastian.Mirkin@pfizer.com

\section{J. H. Pickar}

Obstetrics and Gynecology, Columbia University Medical Center, PO Box 415,

Bulger, PA 15019, USA

e-mail: jhpickar@me.com

\section{Introduction}

During the menopausal transition, women experience a decline in estrogen production [1] that may result in undesirable symptoms such as hot flushes and symptoms associated with vulvar/vaginal atrophy (VVA), as well as loss of bone mass leading to an increased risk of osteoporosis [2]. Vasomotor symptoms (VMS) and VVA can cause physical discomfort and interfere with sleep and daily activities, resulting in a decreased quality of life for postmenopausal women [2]. Additionally, development of postmenopausal osteoporosis increases the risk of bone fractures, which are associated with significant morbidity and increased mortality [3-5]. As the number of postmenopausal women worldwide continues to increase [6॰], menopause-related health issues can impose a significant social and economic burden. The management of menopausal symptoms and the treatment of menopauserelated conditions are therefore global health concerns.

The established treatment options for menopausal symptoms include estrogen therapy (ET) and combined estrogenprogestin therapy (EPT) for postmenopausal women with an intact uterus. ET and EPT are indicated for the treatment of moderate to severe VMS and VVA and are also approved for the prevention of postmenopausal osteoporosis [7]. The inclusion of progestin in EPT is important for protecting the endometrium in nonhysterectomized women. However, EPT has been associated with some safety and tolerability concerns, including stimulation of the breast [8] and irregular vaginal bleeding $[9,10]$. Thus, there is a need for new therapies with improved safety and tolerability profiles that can provide comprehensive relief of menopausal symptoms and preserve bone mass while ensuring endometrial and breast safety.

A novel therapy under development is the tissue-selective estrogen complex (TSEC), which partners a selective estrogen receptor modulator (SERM) with one or more estrogens 
for a clinical profile that is a blend of the properties of the individual components [11]. An effective TSEC would combine the efficacy of estrogens in treating VMS and VVA and preventing osteoporosis with the protective effects of a SERM in the uterus and breast. Based on promising preclinical findings that bazedoxifene (BZA) inhibited estrogen-induced increases in rat uterine wet weight and stimulation of breast cancer cells [12-14], the pairing of BZA with conjugated estrogens (CE) was further evaluated in clinical studies and is the first TSEC in clinical development.

\section{Clinical Studies of BZA/CE}

$\mathrm{BZA} / \mathrm{CE}$ has been evaluated in a series of multicenter, randomized, double-blind, placebo-controlled and activecontrolled phase 3 trials known as the Selective estrogens, Menopause, And Response to Therapy (SMART) trials. Detailed methodology for these trials has previously been reported $[15 \bullet \bullet, 16 \bullet, 17 \bullet]$. The SMART-1 trial $(N=3,397)$ was conducted at 94 sites in the United States, Europe, and Brazil and enrolled generally healthy, postmenopausal women 40 to 75 years of age $[15 \bullet \bullet, 18 \bullet, 19 \bullet, 20 \bullet \cdot$. Eligible subjects had to have an intact uterus, a body mass index (BMI) $\leq 32.2 \mathrm{~kg} / \mathrm{m}^{2}$, and acceptable endometrial biopsy results at screening. This study evaluated the efficacy and safety of BZA 10, 20, and $40 \mathrm{mg} / \mathrm{CE} 0.45$ and $0.625 \mathrm{mg}$ compared with those of raloxifene $60 \mathrm{mg}$ and placebo over 2 years of treatment. The primary endpoint was the incidence of endometrial hyperplasia at 1 year; secondary endpoints included changes from baseline in bone mineral density (BMD), serum bone turnover marker levels, and the frequency and severity of hot flushes. Based on results from this trial showing that BZA $20 \mathrm{mg}$ is the lowest effective dose for protecting the endometrium from estrogen stimulation [20••], the doses selected for evaluation in the subsequent SMART-2 and SMART-3 trials were BZA $20 \mathrm{mg} / \mathrm{CE} 0.45$ and $0.625 \mathrm{mg}$.

The SMART-2 trial $(N=318)$ was conducted at 43 sites in the United States and enrolled healthy, postmenopausal women 40 to 65 years of age with an intact uterus and a $\mathrm{BMI} \leq 34.0 \mathrm{~kg} / \mathrm{m}^{2}[16 \bullet, 21]$. Eligible subjects had to have 7 or more moderate to severe hot flushes daily (or at least 50 per week) at screening and be seeking treatment for hot flushes. This study evaluated the effects of BZA $20 \mathrm{mg} /$ CE 0.45 and $0.625 \mathrm{mg}$ on VMS compared with the effects of placebo over 12 weeks of treatment. The primary endpoint was the change from baseline in the frequency and severity of hot flushes. Secondary endpoints included effects on sleep, quality of life, and satisfaction with treatment.

The SMART-3 trial $(N=652)$ was conducted at 66 sites in the United States and enrolled generally healthy, postmenopausal women 40 to 65 years of age with an intact uterus and a BMI $\leq 34.0 \mathrm{~kg} / \mathrm{m}^{2}[17 \bullet, 22]$. All women had to have a vaginal cytologic smear showing no more than $5 \%$ superficial cells, a vaginal $\mathrm{pH}$ higher than 5, and at least one moderate to severe VVA symptom at screening. This study examined the effects of BZA $20 \mathrm{mg} / \mathrm{CE} 0.45$ and $0.625 \mathrm{mg}$ compared with those of BZA $20 \mathrm{mg}$ and placebo on measures of VVA over 12 weeks of treatment. Secondary endpoints included the impact on sexual function, quality of life, and satisfaction with treatment.

\section{Efficacy on Vasomotor Symptoms}

In the SMART-1 trial, the efficacy of BZA/CE on VMS was evaluated in a subgroup of women with 7 or more moderate to severe hot flushes per day at baseline $(n=216)$ [15••]. All doses of BZA/CE (BZA 10, 20, and $40 \mathrm{mg} / \mathrm{CE} 0.45$ and $0.625 \mathrm{mg}$ ) showed a significantly greater reduction from baseline in the mean daily number of moderate to severe hot flushes than placebo at weeks 5 to $12(P<0.05$; Table 1$)$. At 12 weeks, BZA/CE reduced the mean daily number of hot flushes from baseline by $51.7 \%$ to $85.7 \%$, compared with $17.1 \%$ for placebo. There was also a significantly greater reduction from baseline in the mean severity of hot flushes compared with placebo at weeks 4 and 12 for the groups taking BZA $10 \mathrm{mg} / \mathrm{CE} 0.45$ or $0.625 \mathrm{mg}$ and at week 12 for the groups taking BZA $20 \mathrm{mg} / \mathrm{CE} 0.45$ or $0.625 \mathrm{mg}$ $(P<0.001$; Table 1). Additionally, BZA 10 and $20 \mathrm{mg} / \mathrm{CE}$ 0.45 and $0.625 \mathrm{mg}$ showed significantly greater reductions in the frequency and severity of hot flushes compared with raloxifene $60 \mathrm{mg}$ at weeks 6 to 12 . The improvement in VMS with BZA 10 and $20 \mathrm{mg} / \mathrm{CE} 0.45$ and $0.625 \mathrm{mg}$ versus placebo was sustained over 2 years of therapy [15••, 23].

In the SMART-2 trial, the effects of BZA $20 \mathrm{mg} / \mathrm{CE} 0.45$ and $0.625 \mathrm{mg}$ on VMS were evaluated in randomized subjects who received at least one dose of their assigned study medication and recorded 5 or more days of data each during the baseline week and at least one on-therapy week. Both BZA/ CE groups showed a significantly greater decrease in the mean daily number of moderate to severe hot flushes compared with placebo at weeks 3 to $12\left(P<0.01\right.$; Table 1 and Fig. 1) [16 ${ }^{\circ}$. At week 12, BZA $20 \mathrm{mg} / \mathrm{CE} 0.45$ and $0.625 \mathrm{mg}$ reduced the mean daily number of hot flushes from baseline by $74 \%$ and $80 \%$, respectively, compared with $51 \%$ for placebo. BZA $20 \mathrm{mg} / \mathrm{CE} 0.45$ and $0.625 \mathrm{mg}$ also showed a significantly greater decrease in the mean severity of hot flushes compared with placebo at weeks 3 to $12(P<0.001)$. Moreover, significantly higher percentages of subjects in the BZA/CE groups had at least a $50 \%$ or $75 \%$ reduction in the number of moderate to severe hot flushes at weeks 4 and 12 compared with placebo $(P<0.001)$. The proportion of women with at least a $75 \%$ reduction at week 12 was $61 \%$ for BZA $20 \mathrm{mg} / \mathrm{CE}$ 
Table 1 Effects of BZA/CE on vasomotor and VVA symptoms and bone

\begin{tabular}{|c|c|c|}
\hline SMART-1 & SMART-2 & SMART-3 \\
\hline \multicolumn{3}{|l|}{ Efficacy on vasomotor and VVA symptoms } \\
\hline $\begin{array}{l}\text { - Significant decrease from baseline in the } \\
\text { mean daily number and severity of hot } \\
\text { flushes at week } 12 \text { for BZA } 10 \text { and } \\
20 \mathrm{mg} / \mathrm{CE} 0.45 \text { and } 0.625 \mathrm{mg} \text { vs PBO } \\
(P<0.05)[15 \bullet \bullet\end{array}$ & $\begin{array}{l}\text { - Significant decrease from baseline in the } \\
\text { mean daily number and severity of hot } \\
\text { flushes at weeks } 3-12 \text { for BZA } 20 \mathrm{mg} / \mathrm{CE} \\
0.45 \text { and } 0.625 \mathrm{mg} \text { vs PBO }(P<0.01)[16 \bullet]\end{array}$ & $\begin{array}{l}\text { - Significant increase in the proportion of } \\
\text { superficial and intermediate cells and } \\
\text { decrease in the proportion of parabasal cells } \\
\text { from baseline at } 12 \text { weeks for BZA } 20 \mathrm{mg} / \\
\mathrm{CE} 0.45 \text { and } 0.625 \mathrm{mg} \text { vs PBO }(P<0.05) \\
{[17 \bullet]}\end{array}$ \\
\hline $\begin{array}{l}\text { - Significant increase in the proportion of } \\
\text { superficial and intermediate cells and } \\
\text { decrease in the proportion of parabasal cells } \\
\text { from baseline at } 2 \text { years for BZA } 10 \mathrm{mg} / \mathrm{CE} \\
0.45 \text { and } 0.625 \mathrm{mg} \text { and BZA } 20 \mathrm{mg} / \mathrm{CE} \\
0.625 \mathrm{mg} \text { vs PBO }(P<0.01)[15 \bullet \cdot]\end{array}$ & & $\begin{array}{l}\text { - Significant decrease from baseline in } \\
\text { vaginal } \mathrm{pH} \text { and improvement in the most } \\
\text { bothersome VVA symptom at } 12 \text { weeks for } \\
\text { BZA } 20 \mathrm{mg} / \mathrm{CE} 0.625 \mathrm{mg} \text { vs PBO } \\
(P<0.05)[17 \cdot]\end{array}$ \\
\hline \multicolumn{3}{|l|}{ Effects on bone } \\
\hline $\begin{array}{l}\text { - Significant increase from baseline in lumbar } \\
\text { spine and total hip BMD at months } 6,12,18 \text {, } \\
\text { and } 24 \text { for BZA } 10,20 \text {, and } 40 \mathrm{mg} / \mathrm{CE} 0.45 \\
\text { and } 0.625 \mathrm{mg} \text { vs PBO }(P<0.05)[19 \bullet] \\
\text { - Significant decrease from baseline in serum } \\
\text { BTM levels at months } 6,12,18 \text {, and } 24 \text { for } \\
\text { BZA } 10,20 \text {, and } 40 \mathrm{mg} / \mathrm{CE} 0.45 \text { and } \\
0.625 \mathrm{mg} \text { vs PBO }(P<0.001)[19 \bullet]\end{array}$ & N/A & N/A \\
\hline
\end{tabular}

$B Z A$ bazedoxifene, $C E$ conjugated estrogens, SMART Selective estrogens, Menopause, And Response to Therapy, $V V A$ vulvar/vaginal atrophy, $P B O$ placebo, $B M D$ bone mineral density, $N / A$ not available, $B T M$ bone turnover marker

$0.45 \mathrm{mg}$ and $73 \%$ for BZA $20 \mathrm{mg} / \mathrm{CE} 0.625 \mathrm{mg}$, compared with $27 \%$ for placebo.

\section{Efficacy on Vulvar/Vaginal Atrophy}

The SMART-1 trial assessed measures of VVA in a subgroup of women with no more than 5\% superficial cells at screening and who had a baseline and at least one on-therapy assessment $(n=1,867)[15 \bullet \cdot$. At 24 months, the groups given BZA $10 \mathrm{mg} / \mathrm{CE} 0.45$ or $0.625 \mathrm{mg}$ or BZA $20 \mathrm{mg} / \mathrm{CE} 0.625 \mathrm{mg}$ showed a significantly greater increase from baseline in the mean proportion of superficial cells compared with placebo $(P<0.01$; Table 1). BZA 10 and $20 \mathrm{mg} / \mathrm{CE} 0.45$ and $0.625 \mathrm{mg}$ also resulted in a greater increase in the mean proportion of
Fig. 1 Effects of BZA/CE on the mean daily number of hot flushes over 12 weeks. Reprinted by permission from Wolters Kluwer Health: Menopause [16•], copyright 2009. The mean daily number of hot flushes was significantly lower compared with placebo for both BZA/CE doses at weeks 3 to $12(P<0.01)$ and for BZA $20 \mathrm{mg} / \mathrm{CE} 0.625 \mathrm{mg}$ at week $2(P<0.01) . B Z A$ bazedoxifene, $C E$ conjugated estrogens, $P B O$ placebo

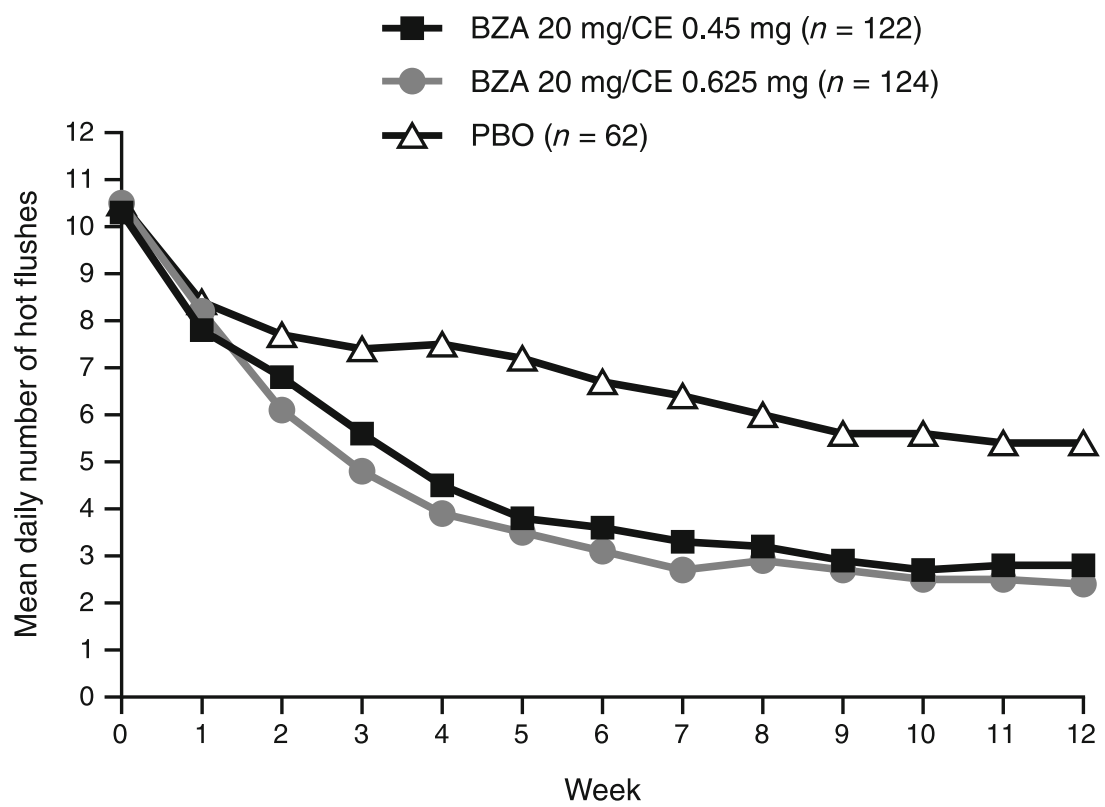


intermediate cells and a greater decrease in the mean proportion of parabasal cells from baseline compared with placebo $(P<0.001)$ at 24 months. Compared with placebo or raloxifene $60 \mathrm{mg}$, there was a significantly lower incidence of dyspareunia for BZA $10 \mathrm{mg} / \mathrm{CE} 0.625 \mathrm{mg}$ at weeks 5 to $8(P<0.05)$ and for BZA $10 \mathrm{mg} / \mathrm{CE} 0.625 \mathrm{mg}$ and BZA $20 \mathrm{mg} / \mathrm{CE} 0.45$ and $0.625 \mathrm{mg}$ at weeks 9 to $12(P<0.05)$.

In the SMART-3 trial, the efficacy of BZA $20 \mathrm{mg} / \mathrm{CE}$ 0.45 and $0.625 \mathrm{mg}$ on VVA was evaluated in subjects who received at least one dose of their assigned study medication and had at least one baseline and one on-therapy value for the parameter being assessed [17•]. At 12 weeks, the groups receiving BZA $20 \mathrm{mg} / \mathrm{CE} 0.45$ or $0.625 \mathrm{mg}$ showed a significantly greater increase from baseline in the mean proportion of superficial cells compared with placebo or BZA $20 \mathrm{mg}(P<0.01$; Table 1). Both BZA/CE groups also showed a significantly greater reduction from baseline in the mean proportion of parabasal cells $(P<0.001)$ and a significantly greater increase from baseline in the mean proportion of intermediate cells $(P<0.05)$ compared with placebo or BZA $20 \mathrm{mg}$ at weeks 4 and 12. Additionally, treatment with BZA $20 \mathrm{mg} / \mathrm{CE} 0.625 \mathrm{mg}$ resulted in a significantly greater decrease from baseline in vaginal $\mathrm{pH}(P<0.001)$ and a greater improvement in the women's most bothersome VVA symptom $(P<0.05)$ compared with placebo or BZA $20 \mathrm{mg}$ at week 12 (Table 1 ). When individual vaginal symptoms were assessed, BZA $20 \mathrm{mg} / \mathrm{CE} 0.45$ and $0.625 \mathrm{mg}$ significantly improved vaginal dryness at 12 weeks compared with BZA $20 \mathrm{mg}(P \leq 0.001)$ and placebo $(P<0.05)$. At 12 weeks, both BZA/CE groups had significantly higher percentages of responders, defined as women with greater than $5 \%$ superficial cells, vaginal $\mathrm{pH}$ lower than 5, and/or improvement from baseline in the most bothersome VVA symptom by at least one category, compared with the groups given BZA $20 \mathrm{mg}$ or placebo. The responder rate was $78 \%$ for BZA $20 \mathrm{mg} / \mathrm{CE} 0.45 \mathrm{mg} ; 81 \%$ for BZA $20 \mathrm{mg} / \mathrm{CE} 0.625 \mathrm{mg} ; 58 \%$ for BZA $20 \mathrm{mg}$; and $66 \%$ for placebo $(P<0.001 \mathrm{vs}$ BZA $20 \mathrm{mg}$ and $P<0.05$ vs placebo).

\section{Effects on Bone}

The SMART-1 trial included two osteoporosis substudies assessing the effects of BZA 10, 20, and $40 \mathrm{mg} / \mathrm{CE} 0.45$ and $0.625 \mathrm{mg}$ on bone. Substudy I $(n=1,454)$ enrolled women whose last menstrual period was more than 5 years prior to screening and who had a BMD T-score between -1 and -2.5 at screening and at least one additional risk factor for osteoporosis. Substudy II $(n=861)$ enrolled women whose last menstrual period was between 1 and 5 years prior to screening and who had at least one risk factor for osteoporosis [19•]. For both substudies, all BZA/CE doses showed significantly greater increases from baseline in lumbar spine BMD at months $6,12,18$, and 24 compared with placebo $(P<0.001$; Table 1). The adjusted annual percentage change from baseline in lumbar spine BMD for the BZA/CE groups ranged from $0.51 \%$ to $1.59 \%$, compared with $-1.08 \%$ for placebo in Substudy I ( $P<0.001$ vs placebo for all), and from $0.55 \%$ to $1.60 \%$ compared with -1.41 for placebo in Substudy II $(P<$ 0.001 vs placebo for all). The percentage of responders for lumbar spine BMD (defined as women with either no change or an increase from baseline in lumbar spine BMD at 12 and 24 months) was significantly higher in all BZA/CE groups compared with placebo $(P<0.001)$ in both substudies: responder rates at month 24 were $63 \%$ to $76 \%$ for BZA/CE versus 30\% for placebo in Substudy I and $61 \%$ to $76 \%$ for $\mathrm{BZA} / \mathrm{CE}$ versus $31 \%$ for placebo in Substudy II. All BZA/CE groups in both substudies also showed significantly greater improvement from baseline in lumbar spine BMD at 24 months compared with raloxifene $60 \mathrm{mg}(P<0.05)$, except for BZA $40 \mathrm{mg} / \mathrm{CE} 0.45$ and $0.625 \mathrm{mg}$ in Substudy I.

All BZA/CE doses showed significantly greater increases from baseline in total hip BMD at months 6, 12, 18, and 24 compared with placebo $(P<0.05)$ in both substudies (Table 1). In Substudy I, significantly greater increases from baseline in BMD at the femoral intertrochanteric, neck, and trochanteric regions were seen for all $\mathrm{BZA} / \mathrm{CE}$ groups compared with placebo at months 12 and $24(P<0.001)$. Similarly, all BZA/CE groups in Substudy II showed significantly greater increases from baseline in BMD at these skeletal sites compared with placebo at months 12 and $24(P<$ 0.05 ), except for BZA $40 \mathrm{mg} / \mathrm{CE} 0.45 \mathrm{mg}$ at the femoral neck at 12 months. Significantly greater improvement from baseline in total hip BMD at 24 months compared with raloxifene $60 \mathrm{mg}(P<0.05)$ was observed for BZA $10 \mathrm{mg} / \mathrm{CE} 0.45$ and $0.625 \mathrm{mg}$ and BZA $20 \mathrm{mg} / \mathrm{CE} 0.625 \mathrm{mg}$ in Substudy I and for BZA $10 \mathrm{mg} / \mathrm{CE} 0.45$ and $0.625 \mathrm{mg}$, BZA $20 \mathrm{mg} / \mathrm{CE}$ $0.45 \mathrm{mg}$, and BZA $40 \mathrm{mg} / \mathrm{CE} 0.625 \mathrm{mg}$ in Substudy II.

The effects of BZA/CE on bone turnover were evaluated in women between 1 and 5 years from menopause (Substudy II) based on the change in serum levels of osteocalcin (OC) and C-telopeptide (CTx). All BZA/CE groups showed a significantly greater reduction from baseline in serum OC and CTx levels compared with placebo at months $6,12,18$, and $24(P<0.001)$. At month 24 , the median percent change from baseline in serum OC levels ranged from $-19.78 \%$ to $-28.05 \%$ for the $\mathrm{BZA} / \mathrm{CE}$ groups compared with $3.08 \%$ for placebo; the change in CTx levels ranged from $-42.72 \%$ to $-53.40 \%$ for the BZA/CE groups compared with $-13.81 \%$ for placebo. The median percentage changes from baseline in serum levels of these markers were also significantly greater for all BZA/CE doses than for raloxifene $60 \mathrm{mg}(P<0.05)$ at 24 months, except for BZA $40 \mathrm{mg} / \mathrm{CE} 0.625 \mathrm{mg}$ for OC at 6 months and BZA $40 \mathrm{mg} / \mathrm{CE} 0.45 \mathrm{mg}$ for CTx at 24 months. 
Safety and Tolerability

\section{Endometrial Safety}

In the SMART-1 trial, the BZA 20- or 40-mg/CE 0.45- or $0.625-\mathrm{mg}$ groups all had low rates of endometrial hyperplasia $(<1 \%)$ at 24 months, similar to the rates observed for placebo (Table 2) [20••]. These BZA/CE doses also showed minimal increases from baseline in endometrial thickness $(<1 \mathrm{~mm})$ at 24 months, which were similar to the increases observed for placebo. In contrast, the groups receiving BZA $10 \mathrm{mg} / \mathrm{CE} 0.45$ or $0.625 \mathrm{mg}$ had endometrial hyperplasia rates of $2.53 \%$ and $7.14 \%$ at 24 months, respectively, and showed significantly greater increases from baseline in endometrial thickness compared with placebo $(P<0.01)$. These data demonstrated that BZA $20 \mathrm{mg}$ was the lowest dose that effectively protected the endometrium from stimulation. Consistent with these findings, the SMART-2 trial showed no significant difference between the BZA 20-mg/ CE 0.45- and 0.625-mg groups and the placebo group in the mean change from baseline in endometrial thickness at week 12 (Table 2) [16•]. The percentage of women who had an increase from baseline in endometrial thickness of greater than $4 \mathrm{~mm}(20 \%$ for BZA/CE and $17 \%$ for placebo) or an increase of greater than $8 \mathrm{~mm}(2.2 \%$ for BZA/CE and $3.8 \%$ for placebo) was also similar between the BZA/CE and placebo groups. No cases of endometrial hyperplasia were reported in the SMART-2 trial, and the SMART-3 trial showed no differences between the BZA $20-\mathrm{mg} / \mathrm{CE} 0.45$ and $0.625-\mathrm{mg}$ groups and the placebo group in the incidence of endometrial disorders (Table 2) [16•,17•].

\section{Breast Safety}

In an ancillary, retrospective study of the SMART-1 trial, the effects of BZA $20 \mathrm{mg} / \mathrm{CE} 0.45$ and $0.625 \mathrm{mg}$ on mammographic breast density were evaluated in a subset of women who completed 2 years of therapy and had mammograms at baseline and year $2(n=507)$. The change from baseline in breast density was similar among the BZA/CE and placebo groups at 2 years: the mean percent change $( \pm \mathrm{SE})$ from baseline was $-0.39 \% \pm 1.75 \%$ for BZA $20 \mathrm{mg} / \mathrm{CE} 0.45 \mathrm{mg}$; $-0.05 \% \pm 1.68 \%$ for BZA $20 \mathrm{mg} / \mathrm{CE} 0.625 \mathrm{mg}$; and $-0.42 \%$ $\pm 1.72 \%$ for placebo (Table 2) [24]. Additionally, a pooled analysis of data for the BZA $20-\mathrm{mg} / \mathrm{CE} 0.45-\mathrm{mg}$ and placebo groups from the SMART-1, SMART-2, and SMART-3 trials showed no differences between the two groups in the incidence of breast-related adverse events (AES; $0.6 \%$ for BZA $20 \mathrm{mg} / \mathrm{CE} 0.45 \mathrm{mg}$ and $0.7 \%$ for placebo) [25]. BZA/ CE treatment also did not increase the incidence of breast

Table 2 Summary of key safety/tolerability findings for BZA/CE

\begin{tabular}{|c|c|c|}
\hline SMART-1 & SMART-2 & SMART-3 \\
\hline \multicolumn{3}{|l|}{ Endometrial safety } \\
\hline $\begin{array}{l}\text { - Low rates of endometrial hyperplasia }(<1 \%) \text { at } \\
2 \text { years for BZA } 20 \text { and } 40 \mathrm{mg} / \mathrm{CE} 0.45 \mathrm{and} \\
0.625 \mathrm{mg} \text {, similar to PBO }[20 \bullet \cdot] \\
\cdot \text { Minimal increases in endometrial thickness } \\
(<1 \mathrm{~mm}) \text { at } 2 \text { years for BZA } 20 \text { and } 40 \mathrm{mg} / \mathrm{CE} \\
0.45 \text { and } 0.625 \mathrm{mg} \text {, similar to } \mathrm{PBO}[20 \bullet \cdot]\end{array}$ & $\begin{array}{l}\text { - No cases of endometrial hyperplasia in any } \\
\text { group }\left[16^{\bullet}\right] \\
\text { - No difference in mean change from baseline in } \\
\text { endometrial thickness at } 12 \text { weeks among the } \\
\text { BZA } 20-\mathrm{mg} / \mathrm{CE} 0.45 \text { - and } 0.625-\mathrm{mg} \text { and PBO } \\
\text { groups }[16 \bullet]\end{array}$ & $\begin{array}{l}\text { - No difference in incidence of endometria } \\
\text { disorders among the BZA } 20-\mathrm{mg} / \mathrm{CE} \\
0.45-\text { and } 0.625-\mathrm{mg} \text { and } \mathrm{PBO} \text { groups } \\
{[17 \cdot]}\end{array}$ \\
\hline \multicolumn{3}{|l|}{ Breast safety } \\
\hline $\begin{array}{l}\text { - No difference in change from baseline in } \\
\text { mammographic breast density at } 2 \text { years } \\
\text { among the BZA } 20-\mathrm{mg} / \mathrm{CE} 0.45-\text { and } \\
0.625-\mathrm{mg} \text { and PBO groups [24] } \\
\text { - No increase in incidence of breast pain for } \\
\text { BZA/CE groups compared with PBO [15••] }\end{array}$ & $\begin{array}{l}\text { - No increase in incidence of breast pain for } \\
\text { BZA/CE groups compared with PBO [16 }]\end{array}$ & $\begin{array}{l}\text { - No increase in incidence of breast pain } \\
\text { for BZA/CE groups compared with PBO } \\
{[17 \bullet]}\end{array}$ \\
\hline \multicolumn{3}{|l|}{ Bleeding-related events } \\
\hline $\begin{array}{l}\text { - High rates of cumulative amenorrhea at } 2 \text { years } \\
\text { for BZA } 20 \text { and } 40 \mathrm{mg} / \mathrm{CE} 0.45 \text { and } 0.625 \mathrm{mg} \text {, } \\
\text { similar to } \mathrm{PBO}[18 \cdot]\end{array}$ & $\mathrm{N} / \mathrm{A}$ & $\mathrm{N} / \mathrm{A}$ \\
\hline \multicolumn{3}{|l|}{ Overall safety and tolerability } \\
\hline $\begin{array}{l}\text { - No difference in overall incidence of AEs } \\
\text { among BZA/CE and PBO groups }[15 \bullet \bullet] \\
\text { - No increase in incidence of VTEs for BZA/CE } \\
\text { groups compared with PBO }[15 \bullet \bullet\end{array}$ & $\begin{array}{l}\text { - No difference in overall incidence of AEs } \\
\text { among BZA/CE and PBO groups [16•] } \\
\text { - No VTEs reported in any group [16•] }\end{array}$ & $\begin{array}{l}\text { - No difference in overall incidence of } \\
\text { AEs among BZA/CE and PBO groups } \\
{[17 \bullet]}\end{array}$ \\
\hline
\end{tabular}

$B Z A$ bazedoxifene, $C E$ conjugated estrogens, SMART Selective estrogens, Menopause, And Response to Therapy, $P B O$ placebo, $N / A$ not available, $A E$ adverse event, $V T E$ venous thromboembolic event 
pain compared with placebo across the three trials (Table 2) $[15 \bullet \cdot, 16,17 \bullet]$.

\section{Bleeding-Related Events}

The rate of cumulative amenorrhea, defined as the percentage of subjects who had no bleeding or spotting over consecutive 4-week cycles, was evaluated in the SMART-1 trial. BZA 20 and $40 \mathrm{mg} / \mathrm{CE} 0.45$ and $0.625 \mathrm{mg}$ were associated with high rates of cumulative amenorrhea ( $>83 \%$ during cycles $1-13$ and $>93 \%$ during cycles 10 13) over 1 year of treatment, similar to that observed with placebo [18•]. The high rates of cumulative amenorrhea for these $\mathrm{BZA} / \mathrm{CE}$ doses were sustained over 2 years of treatment (Table 2) [26]. The BZA 20- and 40-mg/CE 0.45- and $0.625 \mathrm{-mg}$ groups also had a low incidence of bleeding or spotting events, similar to placebo. In contrast, BZA $10 \mathrm{mg} /$ CE 0.45 and $0.625 \mathrm{mg}$ showed slightly lower cumulative amenorrhea rates compared with placebo. There were no differences in the incidence of bleeding-related AEs for BZA $10 \mathrm{mg} / \mathrm{CE} 0.45 \mathrm{mg}$ and BZA 20 and $40 \mathrm{mg} / \mathrm{CE} 0.45$ and $0.625 \mathrm{mg}$ compared with placebo. Consistent with this, a pooled analysis of data for the groups receiving BZA $20 \mathrm{mg} / \mathrm{CE} 0.45 \mathrm{mg}$ or placebo from the SMART-1, SMART-2, and SMART-3 trials showed that the incidences of bleeding-related adverse events were low and similar among the two groups [25].

\section{General Safety and Tolerability}

Overall, there were no significant differences between the BZA/CE and placebo groups in the incidence of AEs or study discontinuations due to AEs across the SMART-1, SMART-2, and SMART-3 trials (Table 2) [15••, 16•, 17•, 25]. The incidence of treatment-emergent AEs (TEAEs) was similar among the BZA/CE and placebo groups (range, $90-94 \%$ vs $92 \%$ in SMART- $1 ; 61-67 \%$ vs $73 \%$ in SMART- $2 ; 75-80 \%$ vs $71 \%$ in SMART-3); most TEAEs were mild to moderate in severity. BZA/CE was not associated with greater incidences of cardiovascular AEs or venous thromboembolic events (VTEs) when compared with placebo [15••, 16•].

\section{Metabolic Parameters}

\section{Lipid Parameters}

In the SMART-1 trial, all BZA/CE groups had a decrease from baseline in total cholesterol at 24 months. This decrease was greater for all BZA/CE groups than for placebo, but the difference was statistically significant only for BZA $20 \mathrm{mg} / \mathrm{CE} 0.45 \mathrm{mg}(P<0.05$ vs placebo; Table 3$)$. All BZA/ $\mathrm{CE}$ doses also resulted in a significantly greater reduction from baseline in low-density lipoprotein (LDL) cholesterol
$(P<0.01)$ and a greater increase in high-density lipoprotein (HDL) cholesterol $(P<0.05)$, compared with placebo [15••]. In the SMART-2 trial, BZA $20 \mathrm{mg} / \mathrm{CE} 0.45$ and $0.625 \mathrm{mg}$ showed significantly greater reductions from baseline in total and LDL cholesterol at 12 weeks compared with placebo $(P<0.05)[16 \bullet]$. Similarly, BZA $20 \mathrm{mg} / \mathrm{CE} 0.45$ and $0.625 \mathrm{mg}$ showed a significantly greater decrease from baseline in LDL cholesterol at 12 weeks compared with placebo $(P<0.01)$ in the SMART-3 trial [17•].

There was a significantly greater increase from baseline in triglycerides for BZA 20 and $40 \mathrm{mg} / \mathrm{CE} 0.625 \mathrm{mg}$ and BZA $20 \mathrm{mg} / \mathrm{CE} 0.45 \mathrm{mg}$ compared with placebo $(P<0.05)$ in the SMART-1 trial and for BZA $20 \mathrm{mg} / \mathrm{CE} 0.625 \mathrm{mg}$ compared with placebo $(P<0.05)$ in the SMART-3 trial (Table 3) $[15 \bullet \cdot, 17 \bullet$. In the SMART-2 trial, the change in triglycerides from baseline was similar between the BZA/ $\mathrm{CE}$ and placebo groups, but a higher proportion of women in the placebo group had increases in triglycerides that were deemed to be potentially clinically important $(>3.7 \mathrm{mmol} / \mathrm{L})$ compared with the BZA/CE groups [16•].

\section{Coagulation Parameters}

Coagulation factors were assessed in the SMART-1 trial $[15 \cdot \bullet]$. At 2 years, there was no effect of BZA/CE on serum concentrations of D-dimer. All BZA/CE doses resulted in decreases from baseline in PAI-1 antigen serum levels $(P<$ 0.05 for BZA $20 \mathrm{mg} / \mathrm{CE} 0.625 \mathrm{mg})$ and PAI- 1 activity $(P<$ 0.05 for BZA 10 and $20 \mathrm{mg} / \mathrm{CE} 0.625 \mathrm{mg}$ and BZA $40 \mathrm{mg} /$ $\mathrm{CE} 0.45 \mathrm{mg}$ ). All BZA/CE groups also showed increases in plasminogen activity from baseline $(P<0.001)$ and significantly greater decreases from baseline in fibrinogen levels, compared with placebo $(P<0.001)$. The change from baseline in protein $\mathrm{C}$ activity was similar between the BZA/CE and placebo groups. All BZA/CE groups showed a significantly greater decrease from baseline in antithrombin III activity $(P<0.05$ vs placebo) and a significantly greater increase from baseline in protein $\mathrm{S}$ activity $(P<0.01$ vs placebo) compared with placebo.

\section{Sleep and Quality of Life}

The effects of BZA $20 \mathrm{mg} / \mathrm{CE} 0.45$ and $0.625 \mathrm{mg}$ on sleep and quality of life were evaluated in the SMART-2 trial in women who received at least one dose of their assigned study medication and had a baseline and at least one on-therapy measurement using the Medical Outcomes Study (MOS) sleep scale and Menopause-Specific Quality of Life (MENQOL) questionnaires. Both BZA/CE doses showed significantly greater improvement from baseline in sleep parameters including time to fall asleep, sleep disturbance, sleep adequacy, and sleep problems indexes I and II compared with placebo $(P<0.001)$ at week 12 (Table 3) 
Table 3 Effects of BZA/CE on metabolic parameters, sleep, and quality of life

\begin{tabular}{|c|c|c|}
\hline SMART-1 & SMART-2 & SMART-3 \\
\hline \multicolumn{3}{|l|}{ Metabolic parameters } \\
\hline $\begin{array}{l}\text { - Significant decrease from baseline in total } \\
\text { cholesterol at } 24 \text { months for BZA } 20 \mathrm{mg} / \mathrm{CE} \\
0.45 \mathrm{mg} \text { vs PBO }(P<0.05)[15 \bullet \bullet]\end{array}$ & \multirow{2}{*}{$\begin{array}{l}\text { - Significant decrease in total and LDL } \\
\text { cholesterol from baseline at } 12 \text { weeks for } \\
\text { BZA } 20 \mathrm{mg} / \mathrm{CE} 0.45 \text { and } 0.625 \mathrm{mg} \text { vs PBO } \\
(P<0.05)[16 \bullet]\end{array}$} & $\begin{array}{l}\text { - Significant decrease in LDL cholesterol from } \\
\text { baseline at } 12 \text { weeks for BZA } 20 \mathrm{mg} / \mathrm{CE} 0.45 \\
\text { and } 0.625 \mathrm{mg} \text { vs PBO }(P<0.01)[17 \cdot]\end{array}$ \\
\hline $\begin{array}{l}\text { - Significant decrease in LDL cholesterol and } \\
\text { increase in HDL cholesterol from baseline at } \\
24 \text { months for BZA } 10,20 \text {, and } 40 \mathrm{mg} / \mathrm{CE} \\
0.45 \text { and } 0.625 \mathrm{mg} \text { vs PBO }(P<0.05)[15 \bullet \cdot] \\
\text { - Significant increase from baseline in } \\
\text { triglycerides for BZA } 20 \mathrm{mg} / \mathrm{CE} 0.45 \text { and } \\
0.625 \mathrm{mg} \text { and BZA } 40 \mathrm{mg} / \mathrm{CE} 0.625 \mathrm{mg} \text { vs } \\
\text { PBO }(P<0.05)[15 \bullet \bullet\end{array}$ & & $\begin{array}{l}\text { - Significant increase from baseline in } \\
\text { triglycerides for BZA } 20 \mathrm{mg} / \mathrm{CE} 0.625 \mathrm{mg} \text { vs } \\
\text { PBO }(P<0.05)[17 \cdot]\end{array}$ \\
\hline \multicolumn{3}{|l|}{ Sleep and quality of life } \\
\hline \multirow[t]{3}{*}{ N/A } & $\begin{array}{l}\text { - Significant improvement in sleep parameters } \\
\text { at } 12 \text { weeks for BZA } 20 \mathrm{mg} / \mathrm{CE} 0.45 \text { and } \\
0.625 \mathrm{mg} \text { vs PBO }(P<0.001)[21]\end{array}$ & $\begin{array}{l}\text { - Significant improvement in total, vasomotor } \\
\text { function, and sexual function MENQOL } \\
\text { scores at } 12 \text { weeks for BZA } 20 \mathrm{mg} / \mathrm{CE} 0.45 \\
\text { and } 0.625 \mathrm{mg} \text { vs PBO }(P<0.05)[22]\end{array}$ \\
\hline & $\begin{array}{l}\text { - Significant improvement in total and } \\
\text { vasomotor function MENQOL scores at } \\
12 \text { weeks for BZA } 20 \mathrm{mg} / \mathrm{CE} 0.45 \text { and } \\
0.625 \mathrm{mg} \text { vs PBO }(P<0.001)[21]\end{array}$ & $\begin{array}{l}\text { - Significantly greater satisfaction with } \\
\text { treatment at } 12 \text { weeks for BZA } 20 \mathrm{mg} / \mathrm{CE} \\
0.45 \text { and } 0.625 \mathrm{mg} \text { vs PBO }(P<0.05)[22]\end{array}$ \\
\hline & $\begin{array}{l}\text { - Significantly greater satisfaction with } \\
\text { treatment at } 12 \text { weeks for BZA } 20 \mathrm{mg} / \mathrm{CE} \\
0.45 \text { and } 0.625 \mathrm{mg} \text { vs PBO }(P<0.05)[21]\end{array}$ & \\
\hline
\end{tabular}

$B Z A$ bazedoxifene, $C E$ conjugated estrogens, $S M A R T$ Selective estrogens, Menopause, And Response to Therapy, $P B O$ placebo, $L D L$ low-density lipoprotein, $H D L$ high-density lipoprotein, $N / A$ not available, $M E N Q O L$ Menopause-Specific Quality of Life

[21]. Significantly greater improvement in sleep quantity was also seen for BZA $20 \mathrm{mg} / \mathrm{CE} 0.625 \mathrm{mg}$ at 12 weeks compared with placebo $(P \leq 0.01)$. Regression analysis showed a significant association $(P<0.05)$ between improvements in sleep parameters and reductions in moderate to severe hot flushes seen with BZA/CE. Both BZA/CE groups showed significantly greater improvement in vasomotor function and total MENQOL scores at 12 weeks compared with placebo $(P<0.001$; Table 3$)$. The BZA/CE groups also had significantly higher percentages of women who reported overall satisfaction with treatment on the Menopause Symptoms Treatment Satisfaction Questionnaire (MS-TSQ) compared with placebo $(73.5 \%$ and $78.2 \%$ for BZA $20 \mathrm{mg} / \mathrm{CE} 0.45$ and $0.625 \mathrm{mg}$, respectively, versus $44.4 \%$ for placebo; $P<0.001$ for both vs placebo).

In the SMART-3 trial, the effects of BZA/CE on sexual function, quality of life, and satisfaction with treatment were evaluated using the Arizona Sexual Experiences (ASEX) scale, the MENQOL questionnaire, and the MS-TSQ [22]. The data were analyzed for all women who were randomized, received at least one dose of their assigned study medication, and had a baseline and at least one on-therapy measurement. The BZA $20-\mathrm{mg} / \mathrm{CE} 0.45-$ and $0.625-\mathrm{mg}$ groups showed significantly greater improvement in ease of lubrication at 12 weeks compared with placebo $(P<$
0.05), as measured on the ASEX scale. Both BZA/CE doses also resulted in significantly greater improvement in vasomotor function, sexual function, and total scores on the MENQOL questionnaire compared with placebo or BZA $20 \mathrm{mg}$ alone at week $12(P<0.05$; Table 3$)$. A significantly greater proportion of BZA/CE-treated women reported overall satisfaction with treatment on the MS-TSQ, compared with those who received placebo or BZA $20 \mathrm{mg}: 62.6 \%$ and $69.4 \%$ for BZA $20 \mathrm{mg} / \mathrm{CE} 0.45$ and $0.625 \mathrm{mg}$, respectively, versus $40.4 \%$ for BZA $20 \mathrm{mg}(P<0.001)$ and $47.4 \%$ for placebo $(P<$ $0.05)$. BZA/CE-treated women were also more satisfied than those in the placebo and BZA 20-mg groups with the ability to control hot flushes during the day and at night $(P<0.001$ for both), the effect on quality of sleep $(P<0.001)$, and the effect on mood or emotions $(P<0.05)$.

\section{Conclusions}

TSECs such as BZA/CE have the potential to provide the favorable effects of estrogens on menopausal symptoms and bone with the protective effects of a SERM on the uterus and breast. In the SMART trials, BZA $20 \mathrm{mg} / \mathrm{CE} 0.45$ and $0.625 \mathrm{mg}$ were shown to be effective in treating menopausal symptoms, including VMS and symptoms of VVA, and in 
preserving bone mass in postmenopausal women. These $\mathrm{BZA} / \mathrm{CE}$ doses were associated with a favorable safety and tolerability profile over 2 years of treatment, including high rates of cumulative amenorrhea and positive effects on the lipid profile, and showed no evidence of endometrial or breast stimulation. BZA/CE-treated women reported significantly improved quality of life and satisfaction with treatment. Thus, BZA/CE may be a promising option for postmenopausal women seeking a comprehensive therapy to treat menopausal symptoms and prevent osteoporosis. The observation in the SMART trials that different doses of BZA/CE have different clinical responses indicates that the ratio of BZA to CE affects the efficacy and safety of the BZA/CE complex. An important consideration for the development of future TSECs will therefore be a careful determination of the optimal ratio of SERM to estrogen(s) to maximize clinical benefit while ensuring safety.

Financial Support Medical writing assistance for this manuscript was provided by Joy Loh, PhD, of MedErgy, and was funded by Pfizer Inc, Collegeville, PA. The authors retained full editorial control over the content of the article.

Disclosure Conflicts of Interest: Sebastian Mirkin, MD, is an employee of Pfizer Inc. James H. Pickar, MD, is a former employee of Wyeth Research and has served as a consultant for Wyeth, Depomed, BHR Pharma, Bionovo, and ASCEND Therapeutics.

\section{References}

Recently published papers of interest have been highlighted as:

- Of importance

-• Of major importance

1. Burger HG, Dudley EC, Robertson DM, Dennerstein L. Hormonal changes in the menopause transition. Recent Prog Horm Res. 2002;57:257-75.

2. Lewis V. Undertreatment of menopausal symptoms and novel options for comprehensive management. Curr Med Res Opin. 2009;25:2689-98.

3. Atik OS, Gunal I, Korkusuz F. Burden of osteoporosis. Clin Orthop Relat Res. 2006;443:19-24.

4. Center JR, Nguyen TV, Schneider D, et al. Mortality after all major types of osteoporotic fracture in men and women: an observational study. Lancet. 1999;353:878-82.

5. Riggs BL, Melton LJI. The worldwide problem of osteoporosis: insights afforded by epidemiology. Bone. 1995;17:505S-11.

6. - Pickar JH, Mirkin S: Tissue-selective agents: selective estrogen receptor modulators and the tissue-selective estrogen complex. Menopause Int. 2010;16:121-128. This article describes the TSEC as a novel therapy option for menopausal symptoms and reviews the clinical findings for $B Z A / C E$.

7. North American Menopause Society. Estrogen and progestogen use in postmenopausal women: 2010 position statement of The
North American Menopause Society. Menopause. 2010;17:24255 .

8. Rossouw JE, Anderson GL, Prentice RL, et al. Risks and benefits of estrogen plus progestin in healthy postmenopausal women: principal results from the Women's Health Initiative randomized controlled trial. JAMA. 2002;288:321-33.

9. Archer DF, Pickar JH, Bottiglioni F. Bleeding patterns in postmenopausal women taking continuous combined or sequential regimens of conjugated estrogens with medroxyprogesterone acetate. Menopause Study Group Obstet Gynecol. 1994;83:686-92.

10. Hammar ML, van de Weijer P, Franke HR, et al. Tibolone and lowdose continuous combined hormone treatment: vaginal bleeding pattern, efficacy and tolerability. BJOG. 2007;114:1522-9.

11. Komm BS. A new approach to menopausal therapy: the tissue selective estrogen complex. Reprod Sci. 2008;15:984-92.

12. Chang KCN, Wang Y, Bodine PV, et al. Gene expression profiling studies of three SERMs and their conjugated estrogen combinations in human breast cancer cells: insights into the unique antagonistic effects of bazedoxifene on conjugated estrogens. J Steroid Biochem Mol Biol. 2010;118:117-24.

13. Kharode Y, Bodine PV, Miller CP, et al. The pairing of a selective estrogen receptor modulator, bazedoxifene, with conjugated estrogens as a new paradigm for the treatment of menopausal symptoms and osteoporosis prevention. Endocrinology. 2008;149:6084-91.

14. Peano BJ, Crabtree JS, Komm BS, et al. Effects of various selective estrogen receptor modulators with or without conjugated estrogens on mouse mammary gland. Endocrinology. 2009;150:1897-903.

15. •• Lobo RA, Pinkerton JV, Gass ML, et al.: Evaluation of bazedoxifene/conjugated estrogens for the treatment of menopausal symptoms and effects on metabolic parameters and overall safety profile. Fertil Steril. 2009;92:1025-1038. This study (SMART-1) demonstrated the efficacy of $B Z A / C E$ in relieving vasomotor and VVA symptoms and its safety over 2 years of treatment.

16. - Pinkerton JV, Utian WH, Constantine GD, et al.: Relief of vasomotor symptoms with the tissue-selective estrogen complex containing bazedoxifene/conjugated estrogens: a randomized, controlled trial. Menopause. 2009;16:1116-1124. This study (SMART2) demonstrated the efficacy of BZA/CE in improving VMS and its safety over 12 weeks of therapy.

17. • Kagan R, Williams RS, Pan K, et al.: A randomized, placebo- and active-controlled trial of bazedoxifene/conjugated estrogens for treatment of moderate to severe vulvar/vaginal atrophy in postmenopausal women. Menopause. 2010;17:281-289. This study (SMART-3) demonstrated the efficacy of BZA/CE on symptoms of VVA and its safety over 12 weeks of therapy.

18. - Archer DF, Lewis V, Carr BR, et al.: Bazedoxifene/conjugated estrogens $(\mathrm{BZA} / \mathrm{CE})$ : incidence of uterine bleeding in postmenopausal women. Fertil Steril. 2009;92:1039-1044. This study (SMART-1) showed that appropriate BZA/CE doses are associated with high rates of cumulative amenorrhea over 2 years of therapy, similar to those for placebo.

19. - Lindsay R, Gallagher JC, Kagan R, et al.: Efficacy of tissueselective estrogen complex of bazedoxifene/conjugated estrogens for osteoporosis prevention in at-risk postmenopausal women. Fertil Steril. 2009;92:1045-1052. This study (SMART-1) demonstrated the efficacy of BZA/CE treatment in preventing bone loss in postmenopausal women over 2 years of therapy.

20. • Pickar JH, Yeh I-T, Bachmann G, Speroff L: Endometrial effects of a tissue selective estrogen complex containing bazedoxifene/ conjugated estrogens as a menopausal therapy. Fertil Steril. 2009;92:1018-1024. This study (SMART-1) showed that BZA/CE did not stimulate the endometrium over 2 years of treatment.

21. Utian W, Yu H, Bobula J, et al. Bazedoxifene/conjugated estrogens and quality of life in postmenopausal women. Maturitas. 2009;63:329-35. 
22. Bachmann G, Bobula J, Mirkin S. Effects of bazedoxifene/conjugated estrogens on quality of life in postmenopausal women with symptoms of vulvar/vaginal atrophy. Climacteric. 2010;13:132-40.

23. Fenton A, Chines A, Mirkin S: Effect of bazedoxifene paired with conjugated estrogens on vasomotor symptoms over 2 years of therapy. Presented at the 4th Triennial Scientific Meeting of the Asia Pacific Menopause Federation. Sydney, Australia; September 26-29, 2010.

24. Harvey JA, Pinkerton JV, Baracat EC, et al.: Evaluation of changes in mammographic breast density associated with bazedoxifene/ conjugated estrogens in postmenopausal women. Endocr Rev 2011, 32. Abstract P1-79.
25. Haines CJ, Pan K, Mirkin S, Chines AA: Safety and tolerability of bazedoxifene and conjugated estrogens: pooled analysis from the Selective estrogens, Menopause And Response to Therapy (SMART)-1, SMART-2, and SMART-3 trials. Presented at the 4th Triennial Scientific Meeting of the Asia Pacific Menopause Federation. Sydney, Australia; September 26-29, 2010.

26. Fenton A, Chines A, Mirkin S: Endometrial safety and bleeding profile of bazedoxifene paired with conjugated estrogens: results from 2 years of therapy. Presented at the 4th Triennial Scientific Meeting of the Asia Pacific Menopause Federation. Sydney, Australia; September 26-29, 2010. 